\title{
INTRODUCTION TO THE 40TH ANNIVERSARY OF THE CZECH SCROLLS
}

Evelyn Friedlander*

The following two essays by Jeremy Adler and Pavel Seifter were given as addresses at the Conference which celebrated the 40th anniversary of the arrival in London of one thousand, five hundred and sixty-four scrolls from Czechoslovakia, where they came into the care of the Memorial Scrolls Trust. Having been ordered to be sent to the Jewish Museum in Prague, the Scrolls which derived from more than one hundred synagogues in Bohemia and Moravia, survived the war and eventually came to be housed under the auspices of the Trust in Westminster Synagogue in London.

From there, as many as possible were repaired, and over the next thirty years more than fourteen hundred were sent to congregations and other institutions throughout the world. With most of them now despatched, the Trust is now concentrating on raising the awareness of recipient congregations to the responsibility that comes with being entrusted with a Memorial Scroll. Recipient communities are asked to dedicate one Shabbat during the year to their Memorial Congregation, to coincide with the anniversary of the deportation of that community and to memorialise the many murdered Jews by remembering their names on that Shabbat and on Yom Hashoah, as well as Yom Kippur. Some congregations have embarked on research projects, and have made contact with the Czech towns.

This impetus is bearing fruit, as many communities have made, or are making, contact with communities in the Czech Republic. Such an example is a Bat Mitzvah held recently in Austerlitz (Slavkov) in the synagogue there, using the original scroll, accompanied by forty-nine congregants from Nottingham. Many congregations, especially in the U.S.A., use their Czech Scroll for Bar and Bat Mitzvah ceremonies. They should be encouraged to take a further step and become more actively and imaginatively involved with the Scroll's past.

* Evelyn Friedlander is the Chair of the Czech Memorial Scrolls Trust and Director of the Hidden Legacy Foundation. 